Article

\title{
Forced Fold Amplitude and Sill Thickness Constrained by Wireline and 3-D Seismic Data Suggest an Elastic Magma-Induced Deformation in Tarim Basin, NW China
}

\author{
Wei Tian *, Xiaomin Li and Lei Wang \\ School of Earth and Space Sciences, Peking University, Beijing 100871, China; lixiaomin@pku.edu.cn (X.L.); \\ thirty@pku.edu.cn (L.W.) \\ * Correspondence: davidtian@pku.edu.cn
}

check for updates

Citation: Tian, W.; Li, X.; Wang, L. Forced Fold Amplitude and Sill Thickness Constrained by Wireline and 3-D Seismic Data Suggest an Elastic Magma-Induced Deformation in Tarim Basin, NW China. Minerals 2021, 11, 293. https://doi.org/ $10.3390 / \min 11030293$

Academic Editor: Craig Magee, Qiliang Sun and William McCarthy

Received: 30 November 2020

Accepted: 1 March 2021

Published: 11 March 2021

Publisher's Note: MDPI stays neutral with regard to jurisdictional claims in published maps and institutional affiliations.

Copyright: (c) 2021 by the authors. Licensee MDPI, Basel, Switzerland. This article is an open access article distributed under the terms and conditions of the Creative Commons Attribution (CC BY) license (https:/ / creativecommons.org/licenses/by/ $4.0 /)$.

\begin{abstract}
Disparities between fold amplitude (A) and intrusion thickness $\left(\mathrm{H}_{\text {sill }}\right)$ are critical in identifying elastic or inelastic deformation in a forced fold. However, accurate measurements of these two parameters are challenging because of the limit in separability and detectability of the seismic data. We combined wireline data and 3-D seismic data from the TZ-47 exploring area in the Tarim Basin, Northwest China, to accurately constrain the fold amplitude and total thickness of sills that induced roof uplift in the terrain. Results from the measurement show that the forced fold amplitude is $155.0 \mathrm{~m}$. After decompaction, the original forced fold amplitude in the area penetrated by the well T47 ranged from 159.9 to $225.8 \mathrm{~m}$, which overlaps the total thickness of the stack of sills recovered by seismic method $(171.4 \mathrm{~m})$ and well $\log$ method $(181.0 \mathrm{~m})$. Therefore, the fold amplitude at T47 area is likely to be elastic. In contrast, the outer area of the TZ-47 forced fold is characterized by shear-style deformation, indicating inelastic deformation at the marginal area. It is suggested that interbedded limestone layers would play an important role in strengthening the roof layers, preventing inelastic deformation during the emplacement of intrusive magma.
\end{abstract}

Keywords: forced fold; elastic; inelastic; saucer-shaped sill; wireline data; seismic cube; velocity pull up; Tarim flood basalt

\section{Introduction}

Shallow-level sills and laccoliths are commonly accommodated by bending and upliftment of the overlying rock and free surface [1-6]. The morphology of this "roof uplift" is considered to mimic the geometry of underlying intrusion(s) and is thus described as a form of "forced fold" [7]. Based on an elastic model, Pollard and Johnson [6] proposed that amplitude of forced folds has a simple relationship with the morphology of subsurface magma: when the intrusion diameter (D) to emplacement depth (d) ratio is $>4$, the original intrusion thickness $\left(\mathrm{H}_{\text {sill }}\right)$ broadly equals the original amplitude $(\mathrm{A})$ of the overlying forced fold (i.e., $\mathrm{A} / \mathrm{H}_{\text {sill }}=1$ ). Therefore, measurement of ground deformation has been widely used in determining the shape of subsurface magma and forecasting volcanic hazard [8-11]

However, recent field, modeling and seismic interpretation studies have questioned the elastic model on the basis that the forced fold amplitude is less than the thickness of subsurface magma in different extents [12]. In addition to elastic uplift, the inelastic space-making process can also accommodate intrusive magma, meaning that the extent of surface uplift may not be equal to that of the underlying magma reservoir [13-18]. Contrastingly, some investigations of sills emplaced at shallow paleolevel do not support the inelastic uplift of the roof strata. For example, Eide et al. [19] noted that sills emplaced at $2.7 \mathrm{~km}$ depth have no disparity, i.e., there was 1 to 1 uplift between intrusion thickness and sill intrusions with no differential vertical uplift. Mark et al. [20] also reported the extensive existence of silicic intrusions in Faroe Shetland basin, which were previously unidentified in the former forced folding studies. Therefore, the comparison between intrusion thickness and deformation intensity is highly debated. 
To address this debate, accurate measurements of the difference between intrusion thickness and forced fold amplitude becomes a critical component in identifying elastic and inelastic deformation in seismically imaged sill-fold pairs [3,21-23]. In practice, direct measuring of sill thickness in active volcanic systems is impossible, and so does measurement with seismic data alone, because the inversion of seismic thickness to true thickness brings significant uncertainty and, in some instances, relies on human perception. Moreover, most of the time, intrusions are too thin to be seen in seismic interpretation practice (e.g., [24,25]). Lack of knowledge of precise thickness of the overburden host rocks in seismic analysis also limits the accurate estimation of amplitude of the forced folds.

In this contribution, we report a combined seismic (i.e., interpreted thickness) and wireline (i.e., true thickness) dataset from a magma intrusion-induced forced fold in Central Tarim Basin, NW China. Based on the comparison of the "forced fold amplitude" (A) and the "sill thickness" $\left(\mathrm{H}_{\text {sill }}\right)$, we show that the elastic deformation of host rocks dominated during the emplacement of the subsurface magma system at the TZ-47 area in the Tarim Basin.

\section{Geological Setting and Data Cube Descriptions}

The Tarim Basin is an endorheic basin occupying an area of over $600,000 \mathrm{~km}^{2}$ in northwest China. It is bounded by the Tianshan Mountains to the north and northwest, the Altyn Mountains to the southeast and the Kunlun Mountains to the southwest (Figure 1). The Taklamakan Desert dominates the surface of the Tarim Basin. A thick succession of Phanerozoic strata, which covers the central parts of the basin, locally exceeds $10 \mathrm{~km}$ in thickness [26]. The basement of the basin is a Precambrian block that is considered to be a fragment of the Rodina Supercontinent $[27,28]$. The Cambrian System consists of a succession of gray to dark gray limestone and dolomite with salt layers, which were deposited in an evaporative/carbonate platform environment [26]. The Ordovician carbonate system is predominantly composed of thick limestone and dolomites associated with an open platform. The Silurian and Devonian sedimentary succession primarily comprises sandstones and mudstones deposited in a tidal-flat environment. The Carboniferous System consists of sandstone and limestone with intercalated mudstone formed in marine-terrigenous facies. Strata in the Permian System are mainly sandstone, mudstone and volcanic lava flows in a terrigenous environment. Major unconformities occur at the Middle-Upper Ordovician boundary, the Silurian-Ordovician boundary and the Permian-Triassic boundary.

The early Permian flood basalt composes the most voluminous volcanic successions in Tarim basin. In the outcrop, the basalts occur in the Kupukuziman Formation and the Kaipazileike Formation [26]. The thickness of the exposed basalt lava flows is up to $780 \mathrm{~m}$ [29], and the maximum thickness of the subsurface basalts exceeds $2500 \mathrm{~m}$ in Northern Tarim [30] and $1100 \mathrm{~m}$ in Central Tarim [31]. The total area of the subsurface lava flows estimated by petroleum industrial drilling, physical logging and seismologic reflection data is over $265,600 \mathrm{~km}^{2}$ (Figure 1). Olivine-tholeiitic basalt lava flows with Ocean Island Basalt (OIB) geochemical signature erupted onto the upper Permian system at $\sim 291-287 \mathrm{Ma}[30,32,33]$. The basalts were subsequently eroded and demarcated by an unconformity between Permian and Triassic strata. 


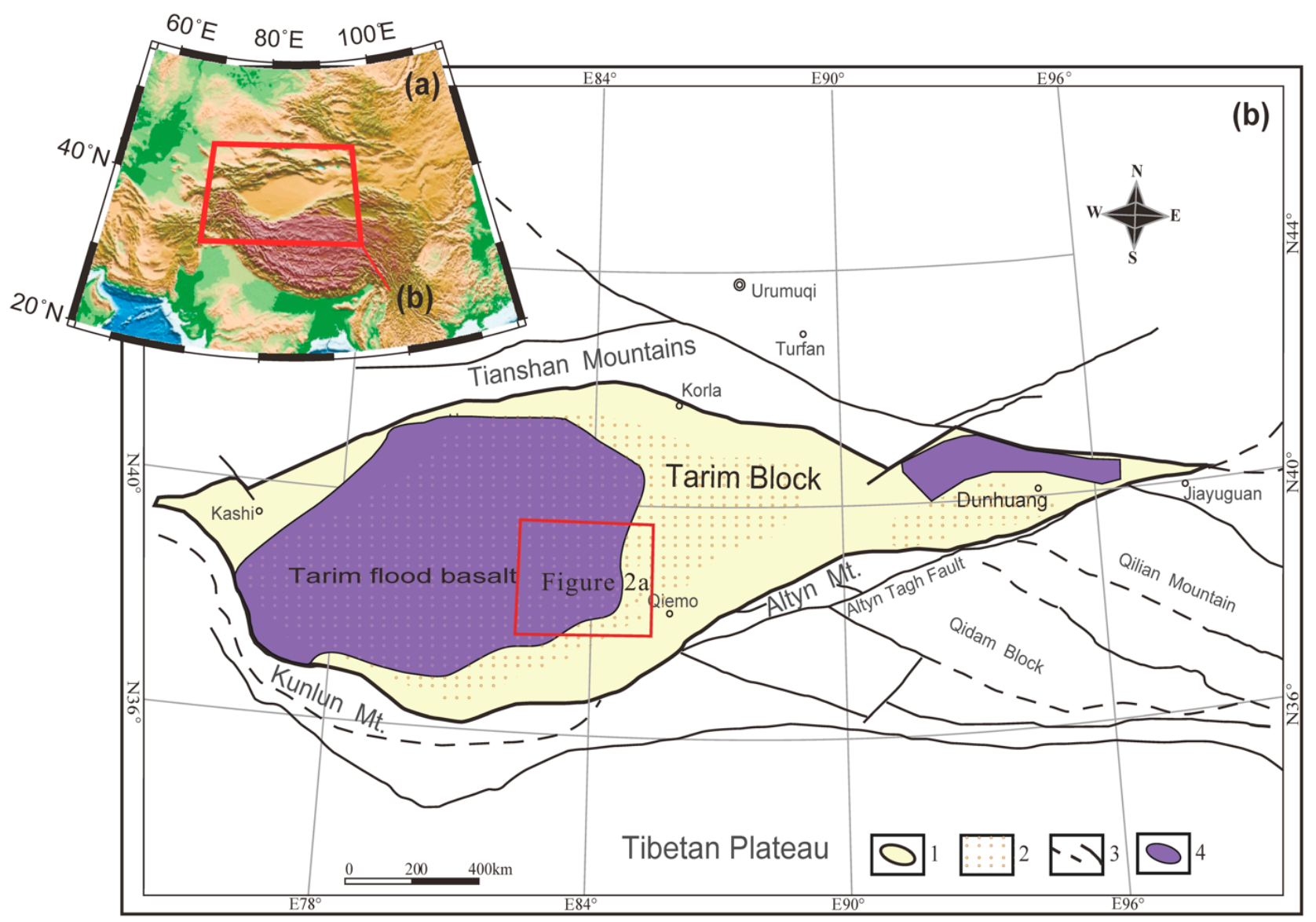

Figure 1. Sketch geological map showing the spatial distribution of the early Permian Tarim flood basalt. Inset map (a) shows a broader view of the Tibetan-Tarim-Tianshan domains. Study area is shown as a rectangle in the regional geological map of Tarim basin (b). Legend in (b): 1, the Tarim Block; 2, desert; 3, major faults; 4, estimated distribution of the Tarim flood basalt.

The TZ-47 field hosts major petroleum and gas reservoirs in the Central Tarim Fields of PetroChina Co. Ltd. Several major faults, including the Tazhong- 1 and Tazhong- 2 faults were surveyed by 3-D industrial seismic interpretation (Figure 2a). Wireline data from 21 wells in the area have revealed the presence of thick basaltic lava flows at depths of 3300-3800 $\mathrm{m}$ across the whole area, as well as subvolcanic facies and volcanic vent facies intrusions at depths of 3900-4500 $\mathrm{m}[31,34]$. All the basalts are underlain by terrestrial sandstone, siltstone, or mudstone, indicating subaerial eruptions. Industrial drilling and seismic interpretation have revealed several central volcanoes [34] (Figure 2b). 

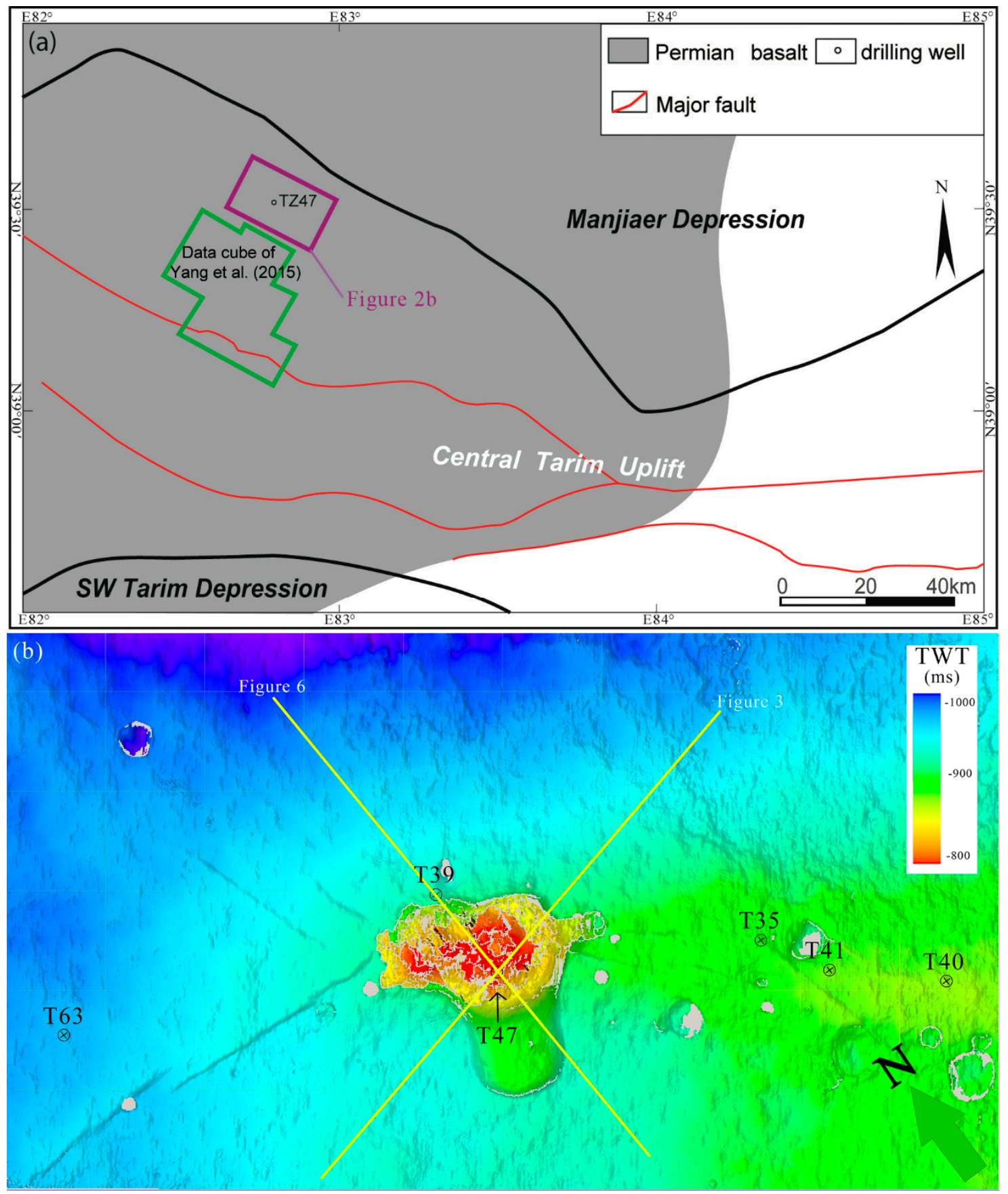

Figure 2. Maps of the study area. (a) Sketch geological map of the Central Tarim uplift showing the tectonic division, major faults and distribution of the Tarim flood basalt. Seismic cube in the study area is shown as purple rectangle in (a), which is to the northeast of the seismic cube studied in Yang et al. [31]; (b) color-visualized T0-isopleth showing the surface of the Permian basalt layer and the locations of the drilling wells in the study area. Thick yellow lines in (b) represent the location of two seismic profiles in Figures 3 and 6. TWT: two-way time.

\section{Data Set and Processing Methods}

The project database consists of a 3-D seismic cube covering approximately $600 \mathrm{~km}^{2}$ in the TZ-47 field (Figure 2a), which is to the north of the data cube of Yang et al. [31]. Six exploration drilling wells that intersect basaltic lava flows or subvolcanic intrusions are shown in Figure $2 b$ to confirm the location of the igneous layers. Data acquisition of the seismic cubes was completed by the Tarim Oil Field Company (TOFC), PetroChina Co. Ltd., with $20 \mathrm{~m}$ line spacing and a positive reflection coefficient represented by positive ampli- 
tude and a black peak. Seismic data were processed by Bureau of Geophysical Prospecting (BGP) Inc., China National Petroleum Corporation. Interpretation was based on the analysis of the pre-stack time-migrated (PSTM) data. Well log data were also supplied by TOFC. The physical logging data of drilling wells were tied to the seismic data by standard synthetic seismogram on the "Petrel E\&P" Software Platform. A stratigraphic column of well T47 interpreted from physical logging data and chips examination (Figure $3 b$ ) is provided to aid the accurate reading of depths of the basalt and two sills; horizon picking was then conducted automatically from these reflectors (Figure 3a).

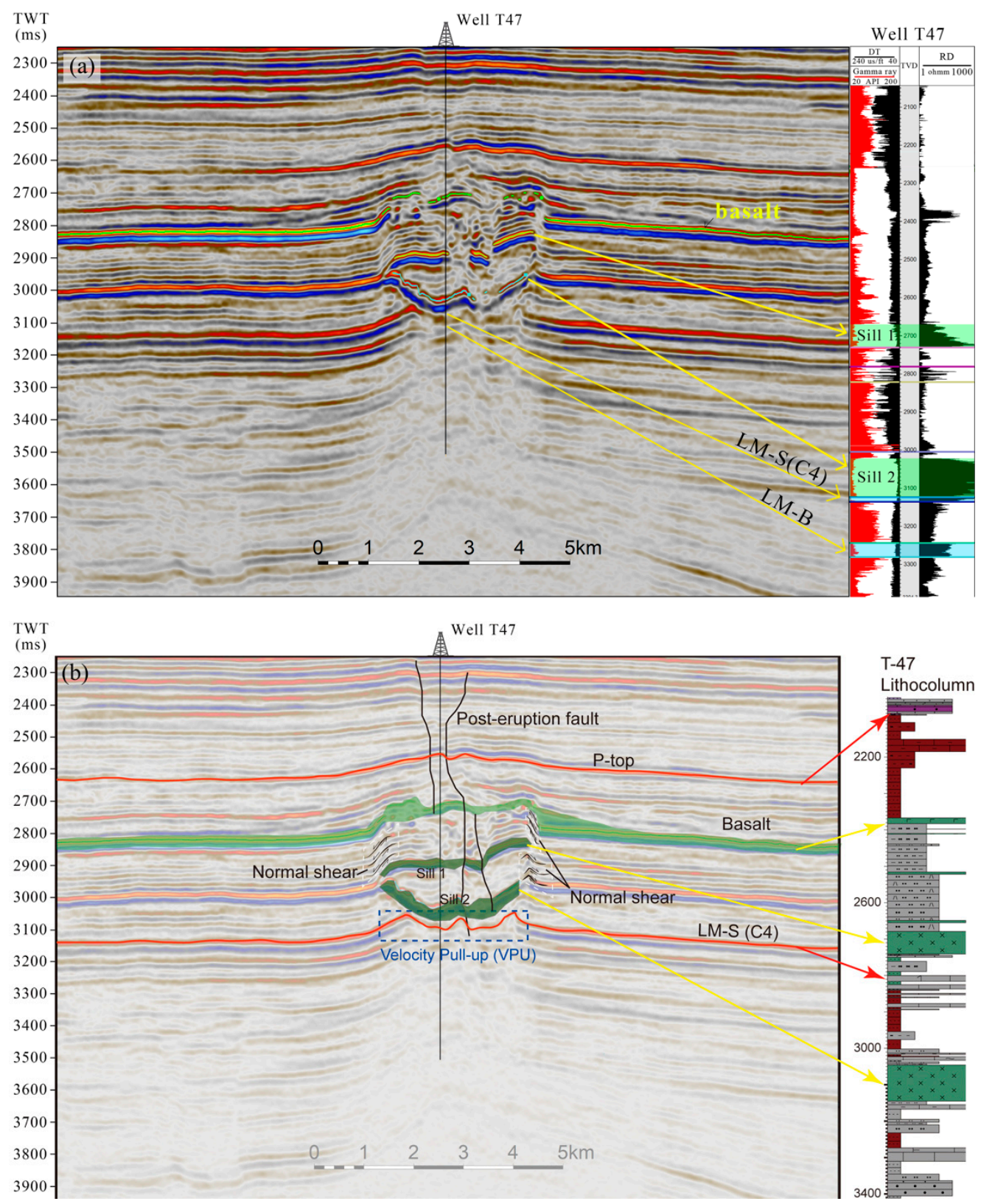

Figure 3. (a) Seismic profile across well TZ-47, illustrating the geometry, scale, and seismic expression of two basaltic sills in TZ-47 area, and their correlations with down-well logging data; (b) interpretation sketch of the seismic profile and its correlation with the lithocolumn of T-47. Acronyms used in well logging data: DT, compressional wave delay time; TVD, true vertical depth sub-sea; RD, deep resistivity; GR, gamma ray. Reflectors, including standard limestones (LM-S), C4 and bioclastic limestones (LM-B) are defined in Section 4.3. 
Basaltic lava flows and sill-like intrusions are typically characterized by very highamplitude reflections in seismic datasets, owing to high-energy reflection at the contacts between basalt and clastic rocks $[35,36]$. Therefore, a basaltic lava flow or intrusion can be easily isolated as a "geo-body" from surrounding clastic rocks in a 3-D seismic dataset by using opacity rendering techniques, which can make the surrounding host-rock transparent [36-40]. In order to obtain the best resolving power, we selected the $50-80 \mathrm{~Hz}$ high frequency components to interpret the basaltic rocks, which have an average velocity of $5500 \mathrm{~m} / \mathrm{s}$. The maximum resolving power or limit of separability of this method equals $\lambda / 8$ [41,42], which is $8.6 \mathrm{~m}(5500 \mathrm{~m} / \mathrm{s} \div 80 \mathrm{~Hz} \div 8)$ that makes it possible to identify sills that are about $10 \mathrm{~m}$ thick.

During the seismic data processing, manual interpretation was combined with automated geo-body extraction, that enabled us to study the morphology and geometry of subsurface igneous sill-dyke networks. The manual operation facilitated a better qualitycontrol on the interpretation, particularly with the randomly distributed sill-dyke networks in clastic sedimentary rocks.

Three sets of well log data, including compressional wave delay time (DT), gamma ray (GR) and deep resistivity (RD), are diagnostic in identifying mafic intrusions in the Tarim Basin. The neutron porosity and caliper logs used effectively in identifying mafic intrusions in the Faroe Shetland basin [20] were not so effective in Tarim Basin. The vertical resolutions of each well log during data collection have been listed in [43]. As for the well logs in Tarim Basin, the data collection interval is $8.13 \mathrm{~cm}$. Therefore, if we can identify the lithology of each interval, the maximum vertical identification power of well log interpretation should be no higher than twice the interval, i.e., $8.13 \times 2=16.26 \mathrm{~cm}$.

In conjunction with the seismic study, an integrated study of the well data, including physical logs, geological reports and mud logs, was carried out in order to identify the sill complexes.

\section{Results}

\subsection{Pre-Deformation Thickness of the Host Strata}

The knowledge of the exact thickness of the host rocks is necessary to accurately measure the amplitude of the forced fold. We used two horizon markers to examine the evenness of the sedimentary strata that underlies the basaltic layer. The upper marker is the top of the lower Permian basalt and the lower marker is the Upper Carboniferous "standard limestone", here named "C4", which is about $1000 \mathrm{~m}$ below the basaltic layer and is uniformly distributed across the Tarim Basin. In petroleum exploration, this limestone reflector " $\mathrm{C} 4$ " is used for basin-wide seismic correlations. The thickness between these two markers is shown as a colored contour map in Figure 4a. It is to be noted that areas subjected to the influence of faulting and volcanic doming were excluded in thickness analysis and are masked by pale gray color.

In the thickness histogram (Figure $4 \mathrm{~b}$ ), the thickness data have a mean value of $643.29 \mathrm{~m}$ with a standard deviation of $9.98 \mathrm{~m}$. However, these data are skewed from normal distribution due to a local high thickness (655-670 m) area in the lower right region, which is marked by a thick dashed red line (Figure 4a). We compare the seismic reflectors of the basaltic lava flow in this area with that from elsewhere and show the contrasting seismic characteristics in Appendix A Figure A1. The bottom reflectors (blue one) of the basaltic layer from the high-thickness area are tuned, which means the thickness of basalt here has reached the tuning limit. Wells T40 and T41, which have basalt thickness of $72 \mathrm{~m}$ and $76 \mathrm{~m}$, show tuning effect; while wells T39 and T35, that have basalt thickness of $52 \mathrm{~m}$ and $62 \mathrm{~m}$, show no tuning effect. This suggests that the tuning point should be slightly lower than $70 \mathrm{~m}$, which is concordant with the tuning point at $25 \mathrm{~Hz}$ main frequency and the velocity of the basalt at $5800 \mathrm{~m} / \mathrm{s}$. Therefore, we can attribute the skew from normal distribution of the thickness data to the extra cumulation of magma layers in the lower right region, which has $\sim 20 \mathrm{~m}$ extra thickness according to the tuning effect of the basalt layer. The $\sim 20 \mathrm{~m}$ extra thickness of the lower right region can be explained by over-cumulation of 
lava flow at a down-slope area, as a result of the pre-eruption uplift of the Tarim flood basalt. The maximum vertical uplift before the eruption of the Tarim flood basalt across

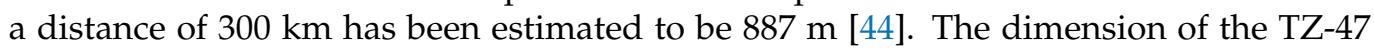
study area is $20-30 \mathrm{~km}$, and the slope fluctuation can be $\sim 60$ to $90 \mathrm{~m}$ if the maximum vertical uplift is applied to this area, although the sloping in this local area seems to be less than one third of the maximum uplift sloping. Another possibility is that the extra stack of sills had created an artificially thickened (overthickened) sequence in this area as a result of the intrusion of the early Permian igneous materials, which may be similar to the basin-wide overthickened sequence recognized in the Faroe-Shetland Basin $[20,24,25]$. When this outlier area is excluded, the thickness distribution becomes much closer to the normal distribution curve shown in Figure 4 b.

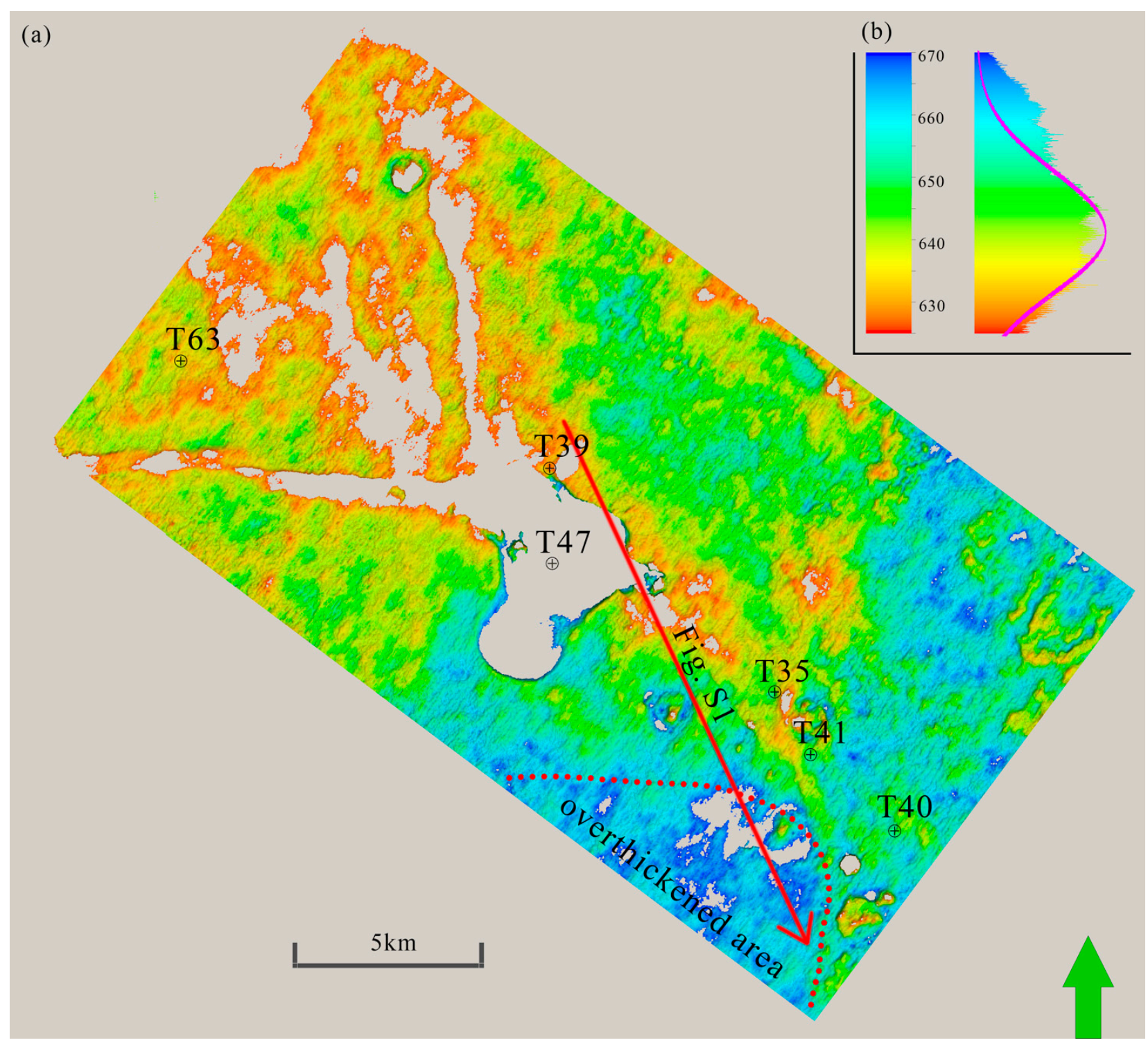

Figure 4. Thickness of the sedimentary strata showing the evenness of the host rocks. (a) Thickness isopleth of strata from the basalt top to the "standard limestone" (C4 reflector), gray color indicating eliminated areas subject to sill intrusion and faulting; (b) statistics of the thickness data. The overall mean value of all thickness data is $643.29 \mathrm{~m}$, with a standard deviation of $9.98 \mathrm{~m}$, which is biased from the normal distribution curve (thick pink line). The bias from normal distribution is mainly due to the existence of overthickened area as circled by dashed red line at lower right of (a). The red arrow indicates the strike of seismic profile Figure A1. 


\subsection{Saucer-Shaped Sills Measured by Combination of Wireline and Seismic Data}

Two major sills, sill 1 and sill 2, can be identified in seismic cross sections passing drilling well T47 (Figure 3a). The "sill 2" intersected by drilling well T47 at a depth of 4100 to $4200 \mathrm{~m}$ (Figure 3a) is a typical saucer-shaped sill, which has been documented in the field survey and seismic interpretation works in many igneous provinces [45-51]. The geo-body corresponding to the top surface of this sill is shown in Figure 5, which has a high-amplitude reflection and is easily extracted from the seismic cube. The thickness of the inner sill of this saucer can be directly measured from the stratigraphic column of T47 (Figures 3a and 6a), which is $100.4 \mathrm{~m}$. Chip and core identifications show that this sill is a typical dolerite. It can be identified in the well logging curves, which is characterized by low gamma value (GR $<30 \mathrm{API})$ and high resistivity $(\mathrm{RD}>8 \mathrm{ohm})$ (Figure 6a). The bottom of this sill is in contact with the "standard limestone", which has a velocity of $6000 \mathrm{~m} / \mathrm{s}$, similar to that of the sill $(5800 \mathrm{~m} / \mathrm{s})$. This makes it difficult to identify the bottom reflector distinctly. We therefore interpret the reflector of the "standard limestone" as the bottom limit of the "sill 2".

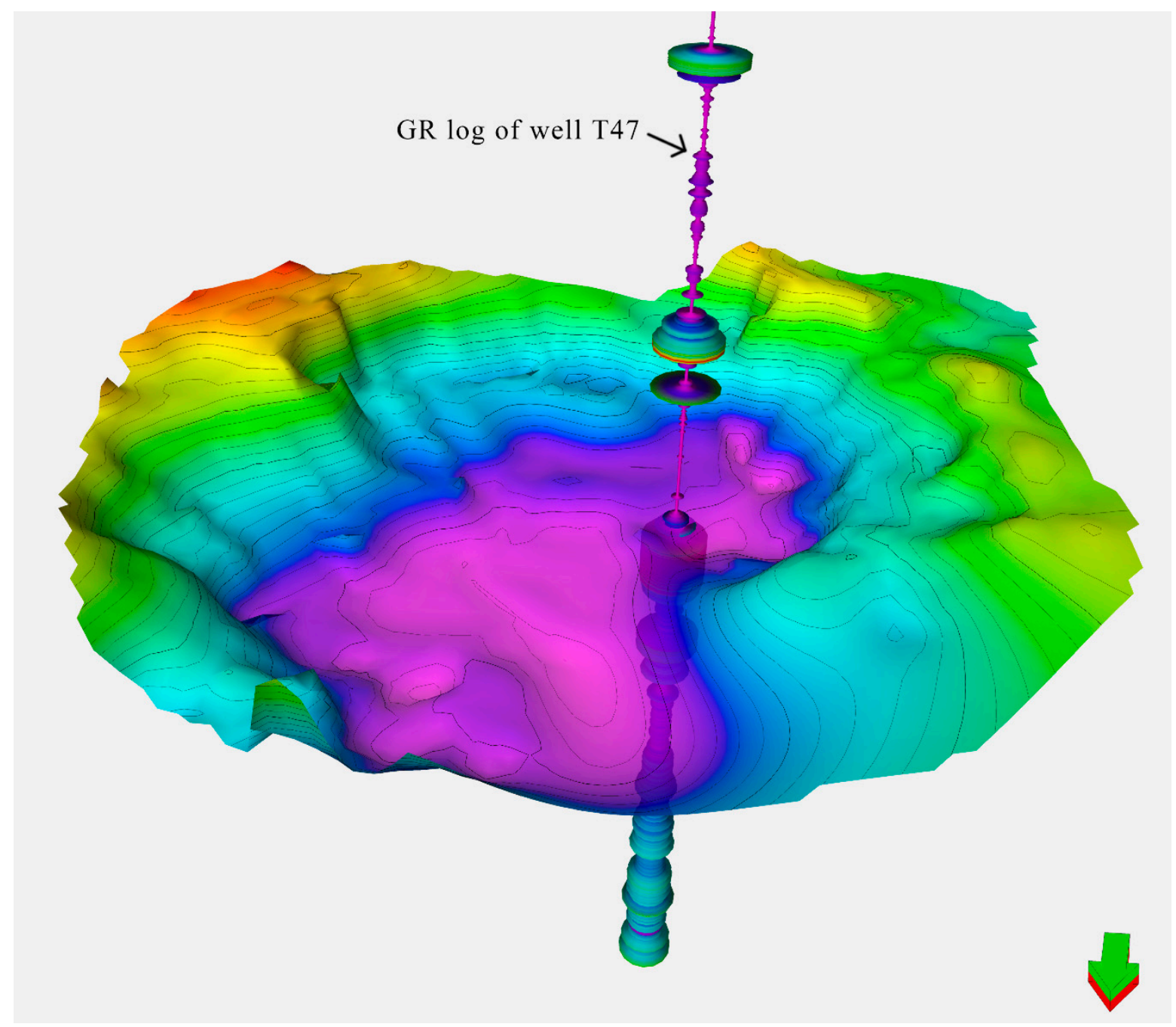

Figure 5. Seismic geo-body of a saucer-shaped sill ("Sill 2" in Figure 3a,b) in three dimensions (3-D) and the location of drilling well T47 which intersected the saucer at depth of 4100-4200 m. The GR log is attached to drilling well T47. 

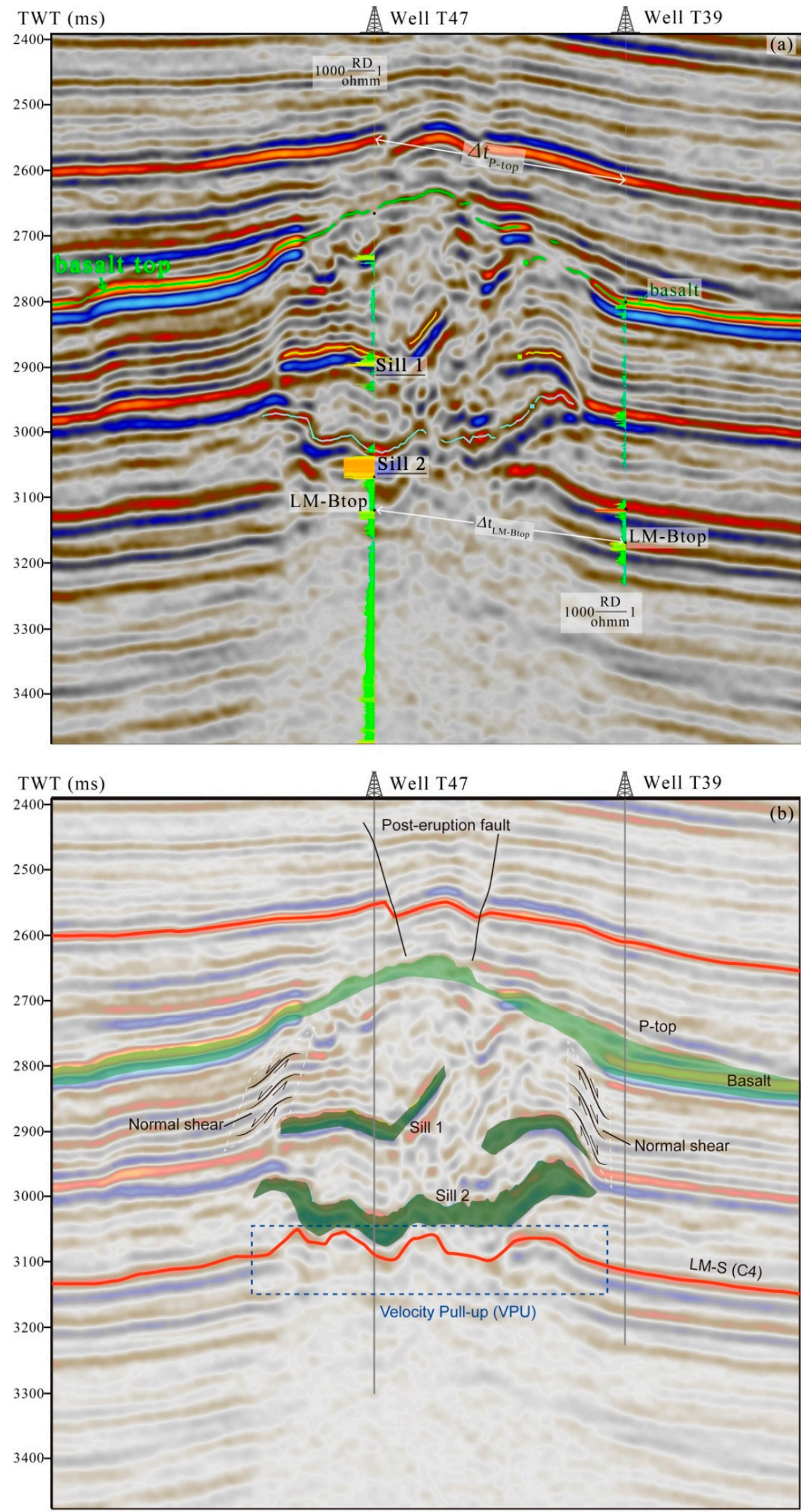

Figure 6. (a) Seismic profile crossing wells T47 and T39. (b) Interpretation sketch of the seismic profile. 
The reflector of "sill 1" is intercalated with several strong reflectors, and it is difficult to extract the geo-body of this sill complex. At the intersection with drilling well T47, the thickness of "sill 1" is recoded as $62.5 \mathrm{~m}$.

The bright green bars show the down-well log data of GR in time domain. The time structure difference of T39 and T47 at the Permian-Triassic boundary (P-top) is $58 \mathrm{~ms}$, while that at the top of the bioclastic limestone (LM-Btop) is $56 \mathrm{~ms}$, suggesting a morphological uplift of $2 \mathrm{~ms}$ at the volcanic center area intersected by well T47.

\subsection{Roof Uplifting Identified in Seismic Cube}

There are three representative drilling wells, T47, T39 and T35, with different distances to the uplift center (Figure 2b)., The drilling well T47 at the uplift center intersects the bioclastic limestone (LM-B), which has marked elevation and deformation as shown in the seismic cross section (Figure 6b). Several high-amplitude bodies intersected by T47 are incased in the horizontal markers, including P-top (Permian-Triassic boundary), basalt-top (B-top), LM-S and LM-Btop. According to the down-well physical logging and the synthetic seismograms, the high-amplitude bodies correspond to seven basaltic layers with thickness ranging from 1.5 to $100.4 \mathrm{~m}$ (Figure 7). The pre-eruption morphology inferred from the shape of LM-Btop suggests a roof uplifting above the sills at T47, which extends to $\sim 4 \mathrm{~km}$ wide area (Figure 2b).

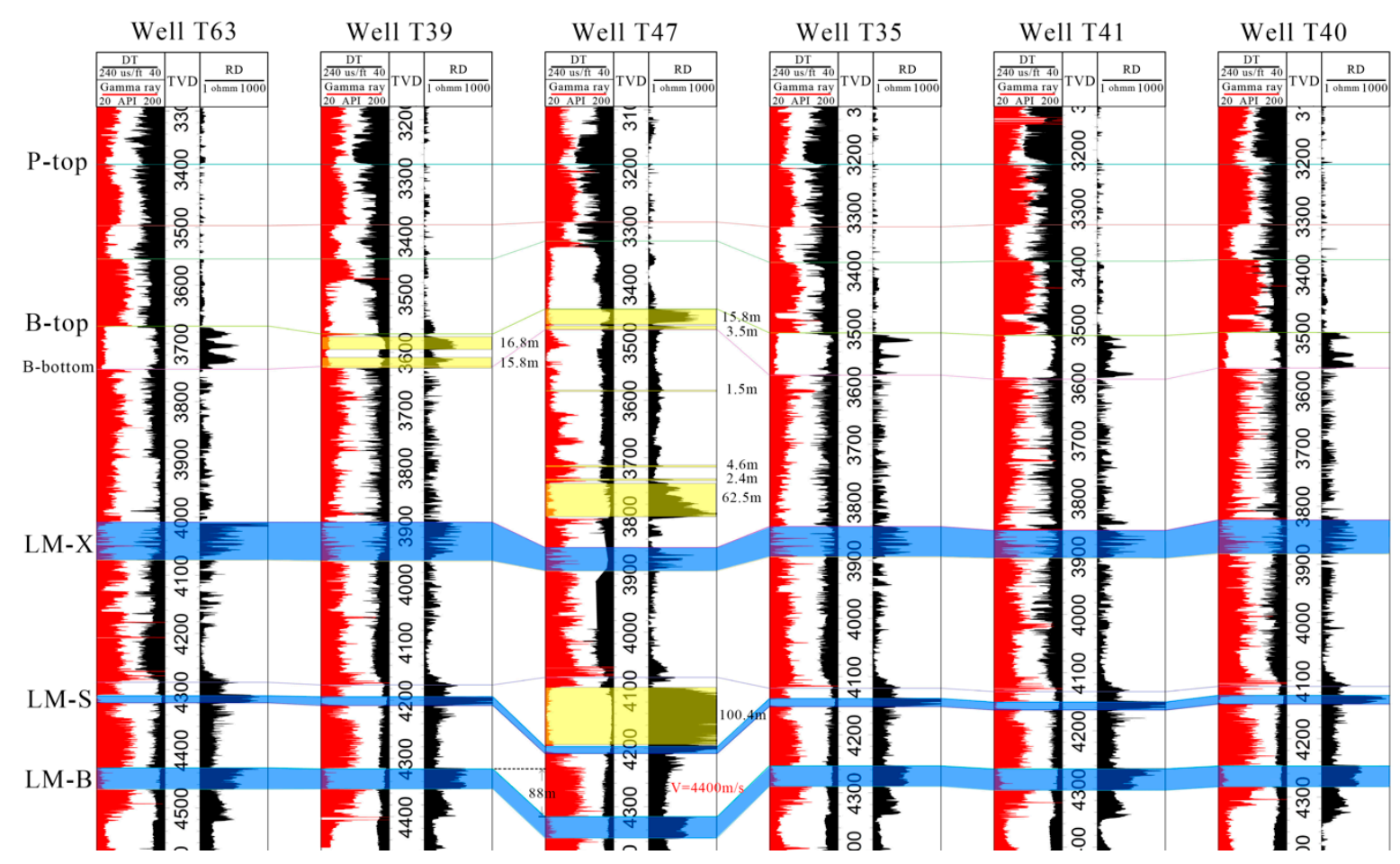

Figure 7. Log profile flattened along the Permian-Triassic (PT) boundary (P-top). Yellow color stands for mafic magmatic rocks. Blue color stands for limestones, which are Xiaohaizi limestones (LM-X), Standard limestones (LM-S) and bioclastic limestones (LM-B), respectively. The top of bioclastic limestones (LM-B) is abbreviated as LM-Btop in the text.

Drilling well T39 is $2476 \mathrm{~m}$ to the northwest of T47 and is located at the margin of the uplifted area. The Permian sedimentary strata show little disturbance by the intrusion of the sills and are similar to the strata distal to the uplifting center, such as well T35, that is 6692 m east of well T47 (Figure 2b). 


\section{Discussion}

\subsection{Sill and Basalt Thickness Estimated by Seismic Method}

Well T39 and well T47 are close enough but they have significant differences in velocity structure. The Paleozoic strata in the T35 column are very similar to those of T39 (Figure 7); while T35 is $6692 \mathrm{~m}$ away from the center (Figure 2b). This significant distance of T35 from other wells can guarantee that the uplifted center had no structural or thermal influence on the T35 area. Therefore, the similarity between T39 and T35 indicates that no remarkable deformation occurred at these two wells. Wireline data also show that well T39 did not intersect any intrusions (Figure 7) and would therefore represent the stratigraphy prior to the deformation induced by the emplacement of magma at the T47 uplifting center.

As shown in Figure 4a, the thickness of the host rock before emplacement of the sills is uniform. Therefore, the net difference between the top and bottom horizontal markers at each location after uplift should reflect the addition of basaltic sills, i.e., a magma intrusioninduced forced fold. However, the reflector of surface basalt lava flow at T47 is not distinct. Therefore, we use a higher reflector, the Permian-Triassic boundary (P-top), as the upper reference reflector to calculate the total thickness of high velocity basalts, including sills and surface lava flows. The net difference between T39 and T47 can be calculated and correlated to the time depth section (Figure $6 \mathrm{~b}$ ) as described below:

(1) Select Permian-Triassic boundary (P-top) as top and bioclast limestone top surface (LM-Btop) as bottom. LM-Btop is beneath all seven magmatic layers at the location of $\mathrm{T} 47$, and is not affected by the igneous intrusions, thus this layer is used as a reference horizontal surface.

(2) The time difference between T39 and T47 at P-top ( $\left.\Delta \mathrm{t}_{\mathrm{p} \text {-top }}\right)$ is $58 \mathrm{~ms}$, and the time difference $\Delta \mathrm{t}_{\mathrm{LM} \text {-Btop }}$ at LM-Btop is $56 \mathrm{~ms}$ (Figure 6b). Comparing T39 and T47, the time thickness difference $\Delta t=\Delta t_{\text {p-top }}-\Delta t_{\text {LM-Btop }}=58-56=2 \mathrm{~ms}$.

(3) Flattening the well logging curves of T39 and T47 along the P-top, which represents a horizontal topography at the eruption time of the Permian flood basalt. The depth difference at LM-Btop between T39 and T47 can be calculated based on the logging data, which is $\Delta \mathrm{h}=88 \mathrm{~m}$.

(4) According to the acoustic logging data (DT), the averaged acoustic velocity of T47 at the lowest $88 \mathrm{~m}$ (shown as $\Delta \mathrm{h}$ in Figure 7) is $\mathrm{V}_{2}=4450 \mathrm{~m} / \mathrm{s}$; the dual time difference corresponding to the depth of difference is $\Delta \mathrm{t}_{1}=\Delta \mathrm{hV}_{2} \times 2 \times 1000=88 / 4450$ $\times 2 \times 1000=40 \mathrm{~ms}$.

(5) Likewise, by using the acoustic logging curve (DT), we can obtain the average velocity between P-top and LM-Btop from the two different lithologies: the average velocity of clastic rock is $V_{\text {low }}=3500 \mathrm{~m} / \mathrm{s}$, the average velocity of mafic magmatic rock is $\mathrm{V}_{\text {high }}=5800 \mathrm{~m} / \mathrm{s}$.

(6) The difference of pull-up time depth $\Delta t_{\mathrm{VPU}}$ due to igneous intrusions is equal to the time-thickness difference between the two wells (obtained in step 2) minus the dual time difference corresponding to the depth of difference (obtained in step 4), i.e., $\Delta \mathrm{t}_{\mathrm{VPU}}=\Delta \mathrm{t}_{1}-\Delta \mathrm{t}=2-40=-38 \mathrm{~ms}$. The negative number here represents that at the direction of the time difference at the velocity pull-up (VPU) case, $\Delta t_{\mathrm{VPU}}$ is negative.

Following the VPU relationship proposed by Jackson et al. [22], we can calculate the total thickness of basalt $(\mathrm{H})$ by using:

$$
\mathrm{H}=\frac{\Delta \mathrm{t}_{\mathrm{vpu}} \mathrm{V}_{\text {low }} \mathrm{V}_{\text {high }}}{\mathrm{V}_{\text {high }}-\mathrm{V}_{\text {low }}}
$$

$\mathrm{H}$ here represents the seismic recovered thickness of the high-velocity basaltic layers; $\mathrm{V}_{\text {high }}$, $\mathrm{V}_{\text {low }}$, and $\Delta \mathrm{t}_{\mathrm{VPU}}$ are defined and obtained in steps 5 and 6.

By using $\mathrm{V}_{\text {high }}=5800 \mathrm{~m} / \mathrm{s}, \mathrm{V}_{\text {low }}=3500 \mathrm{~m} / \mathrm{s}$ and $\Delta \mathrm{t}_{\mathrm{VPU}}=38 \mathrm{~ms}$, the seismically recovered total thickness of the basaltic layers intersected by well T47 $(\mathrm{H})$ is $167.7 \mathrm{~m}$, and the total sill thickness $\left(\mathrm{H}_{\text {sill }}\right)$ intersected by well T47 can be obtained by removing the thickness difference of surface lava flows between T47 and T39, which is $167.7-(15.8+3.5)$ 
$+(16.8+15.8)=181.0 \mathrm{~m}$. This result is greater than the total thickness of the sills intersected by $\mathrm{T} 47$, which is $100.4+62.5+2.4+4.6+1.5=171.4 \mathrm{~m}$, suggesting that some thin sills below the well log resolution may have not been identified [20].

\subsection{Forced Fold Amplitude Measured by Wireline Data}

Down-slope flowing of lava may influence the thickness of basaltic piles [52]. This means that the basaltic flows at the outer rim of the forced fold may experience extra accumulation of magma while that at the central top of the forced fold may accumulate less thickness. Therefore, we use the bottom of the earliest basalt lava flow to represent the surface topography before basalt eruption. This can eliminate the effect of down slope magma flowing. Based on the logging data shown in Figure 7, we can calculate the forced fold amplitude (A) by measuring the thickness difference between well T39 and well T47 immediately after the forced folding. This is calculated by comparing the distances from basalt bottom to the bottom of LM-S at T39 and T47. Depth of basalt bottom (B-bottom) is $2572.0 \mathrm{~m}$ at T39 and is $2402.0 \mathrm{~m}$ at T47; depth of standard limestone bottom (LM-S) is $3151.0 \mathrm{~m}$ at T39 and is $3136.0 \mathrm{~m}$ at T47. The forced fold amplitude (A) at well T47 is $(3136.0-2402.0)-(3151.0-2572.0)=155.0 \mathrm{~m}$.

If we use the top of the basalt (B-top) as the upper reference surface, the forced fold amplitude at well T47 is $141.0 \mathrm{~m}$ when compared to the corresponding reflectors intersected by T39. The decrease in the forced fold amplitude calculated by these reflectors is due to the uneven basalt thickness, which can be read from the seismic section (Figure 6a,b). We interpret the unevenness of the basaltic layer thickness as a consequence of low viscosity basaltic lava that allows the lava to accumulate into the downstream area when the surface slope is high.

\subsection{Comparison between Fold Amplitude and Sill Thickness}

If we assume that the forced folding of the overlain strata accommodates the intruded magma volume, the roof uplift amplitude should equal the thickness of the intrusion, if the folding is elastic [2]. However, the fold amplitude $(\mathrm{A}=155.0 \mathrm{~m})$ is smaller than the seismically inferred total sill thickness $\left(\mathrm{H}_{\text {sill }}=181.0 \mathrm{~m}\right)$ and the wireline-based total sill thickness $\left(\mathrm{H}_{\text {sill }}=171.4 \mathrm{~m}\right)$ at well $\mathrm{T} 47$, which is not expected in an elastic model. If we do the decompaction following the method of Magee et al. [12], the original fold amplitude will be in the range of 159.9 to $225.8 \mathrm{~m}$. This range overlaps the sill thickness recovered by seismic method $(171.4 \mathrm{~m})$ and well $\log$ method $(181.0 \mathrm{~m})$. Although there is a big uncertainty, the forced fold amplitude at the area penetrated by well T47 is consistent with the total sill thickness in the same area.

However, shear-mode displacement can be observed along the bounding ring fault in the overburden of the TZ-47 forced fold. As shown in Figures $3 b$ and $6 b$, there are normal shear patterns at the tips of the sills, which are typical in inelastic forced folds ([53]). Because of the upliftment of the footwall above the sills, the $\sigma_{3}$ would rotate to subhorizontal orientation and further intrusion of the magma would cease [50]. This also explains why the area penetrated by well T39 was not intersected by sills.

\subsection{Possible Sources of Error in Seismic Studies of Forced Folds}

Most forced folding analyses by seismic methods are limited by the separability and detectability, which is about ten meters and several tens of meters, respectively [11,54]. Sills with thicknesses between 5 and $40 \mathrm{~m}$ are at the limit of seismic resolution, and hence are not identified pre-drill $[24,25]$. This means an error of up to several tens of meters while estimating folding amplitude. A more accurate way to constrain the fold amplitude and sill thickness is using drilling well data, by which sills thicker than $1 \mathrm{~m}$ can be identified $[24,25]$. Furthermore, if the sills are $<1 \mathrm{~m}$ thick, it may be missed even by well log data [25]. In this study, the sills were intersected by several drilling wells and the lithologies were recorded by physical logging data. The concordant results of $\mathrm{A}$ and $\mathrm{H}_{\text {sill }}$ indicate that the space-making mechanism was elastic deformation. As shown in Figure 7, three out 
of five sills have a thickness ranging from 1.5 to $4.6 \mathrm{~m}$, which is below the separability at main frequency of $\sim 25 \mathrm{~Hz}$ and velocity range of $4000-7500 \mathrm{~m} / \mathrm{s}$ for igneous intrusions [54]. In the seismic cross sections (Figure $3 \mathrm{a}, \mathrm{b}$ ), these sills are seismically undetectable, and the fold amplitude (A) would be greater than the total thickness of sills $\left(\mathrm{H}_{\text {sill }}\right)$. This is demonstrated by a schematic cartoon shown in Figure 8a. When a thin sedimentary stratum is interbedded with two sills (Figure 8b), the seismic reflector may also be invisible if the thin sedimentary bed is below the resolving power. In this case, the total thickness of the sills is overestimated due to the invisibility of interbedded sedimentary layer in the seismic cube.

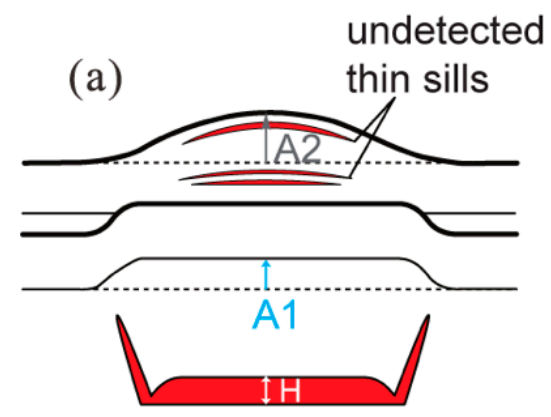

$\mathrm{A} 2>\mathrm{A} 1=\mathrm{H}$ (b)

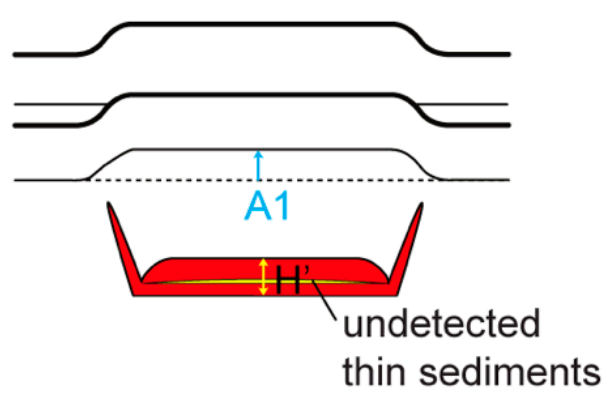

$\mathrm{A}=\mathrm{H}<\mathrm{H}^{\prime}$

Sill $\uparrow$ Uplift direction and amplitude

\section{$\llbracket \rrbracket$ Real sill thickness $(\mathrm{H}) \quad \uparrow$ Apparent sill thickness $\mathrm{H}^{\prime}$}

Figure 8. Models showing how the ratio of fold amplitude (A) and sill thickness $\left(\mathrm{H}_{\text {sill }}\right)$ is overestimated or underestimated (modified after ref. [11]). (a) Schematic showing how the occurrence of seismically undetected, thin sills within the fold could produce the observed upward increase in fold amplitude, and the observed $\mathrm{A} 2 / \mathrm{H}$ would be $>1$, which is larger than the real $\mathrm{A} / \mathrm{H}_{\text {sill }}$; (b) Schematic showing how the occurrence of seismically undetected, thin sedimentary layers within sills lead to overestimation of sill thickness, and the observed $\mathrm{A} / \mathrm{H}^{\prime}$ would be $<1$, which is smaller than the real $\mathrm{A} / \mathrm{H}_{\text {sill }}$.

In summary, the accuracy of fold amplitude and sill thickness is highly dependent on separability and detectability of the seismic method $[11,54]$ when we study the elastic and inelastic deformation components in a sill-induced forced folding process. Large uncertainties may occur if there are plenty of interbedded thin sills or thin sedimentary layers. Wireline data provide a better choice in measuring these parameters.

\subsection{The Possible Role of Limestone Layers in Hardening Up of the Roof Layers}

One important lithological feature of the roof section in the TZ- 47 area is the occurrence of several limestone-dominated layers, including the Xiaohaizi Formation limestone (LM-X), the standard limestone (LM-S) and the bioclastic limestone (LM-B). Using the empirical formula for S-wave velocity prediction in Central Tarim [55], we obtain the Young's modulus of limestone and clastic rocks, which are 59-69 GPa and 8-30 GPa, respectively. Since the diagenesis on burial for the marine facies limestones happened earlier [56], these Carboniferous limestone layers should have effectively hardened up and would have been able to resist the volume of the early Permian magma that has been taken up in the localized host rock deformation. This suggests that the existence of multiple layers of limestones may be significant in enhancing the strength of the roof rocks. The occurrence of multi-layers of limestone may also be an explanation for the near 1 to 1 uplift of the TZ- 47 forced fold between sill thickness and fold amplitude. We therefore propose that much of the localized 
host rock deformation accommodating sill thickness at shallow levels happens because of the ability for pore space collapse to occur, while this inelastic deformation would cease if the limestone layers in the roof section would undergo diagenesis earlier. Further exploration on the deformation style of limestone-bearing sections would be valuable in the evaluation of this hypothesis.

\section{Conclusions}

By the interpretation of 3-D seismic data and down-well logging data from the TZ-47 field, we found that:

(1) The TZ-47 fold represents overburden deformation above a stack of magmatic sills intruded in the Tarim Basin, NW China;

(2) The amplitude of roof uplift at the area penetrated by well T47 is $155.0 \mathrm{~m}$;

(3) The total sill thickness estimated by the seismic method is $171.4 \mathrm{~m}$ and that calculated by the well $\log$ method is $181.0 \mathrm{~m}$, which are consistent with the decompacted roof uplift amplitude ( 159.9 to $225.8 \mathrm{~m}$ ), suggesting a dominantly elastic deformation of this forced fold;

(4) When using just the seismic method, we may miss some invisible sills and interbedded sedimentary strata, as well as vertical structural features, which may result in underestimation or overestimation of sill thickness, respectively;

(5) Carbonate layers may have played an important role in the hardening up of the roof layers and in helping to avoid inelastic deformations.

Author Contributions: Conceptualization, W.T.; methodology, L.W. and X.L.; validation, W.T.; formal analysis, X.L.; investigation, X.L.; resources, W.T. and L.W.; data curation, L.W.; writing—original draft preparation, W.T.; visualization, X.L.; supervision, W.T.; project administration, W.T.; funding acquisition, W.T. All authors have read and agreed to the published version of the manuscript.

Funding: This research was funded by NSFC to WT, grant No. 41630205.

Acknowledgments: $\mathrm{C}$. Magee is acknowledged for his thorough and thoughtful review on a former version and the current version of this manuscript. Comments and suggestions from two anonymous reviewers highly improve the quality of the manuscript. The Tarim Oil Field Company (TOFC), PetroChina Co. Ltd., is acknowledged for kindly providing seismic and wireline data for this research. The authors would also like to thank Durgalakshmi from ANU for improving the English.

Conflicts of Interest: The authors declare no conflict of interest. The funders had no role in the design of the study; in the collection, analyses, or interpretation of data; in the writing of the manuscript, or in the decision to publish the results. 


\section{Appendix A}
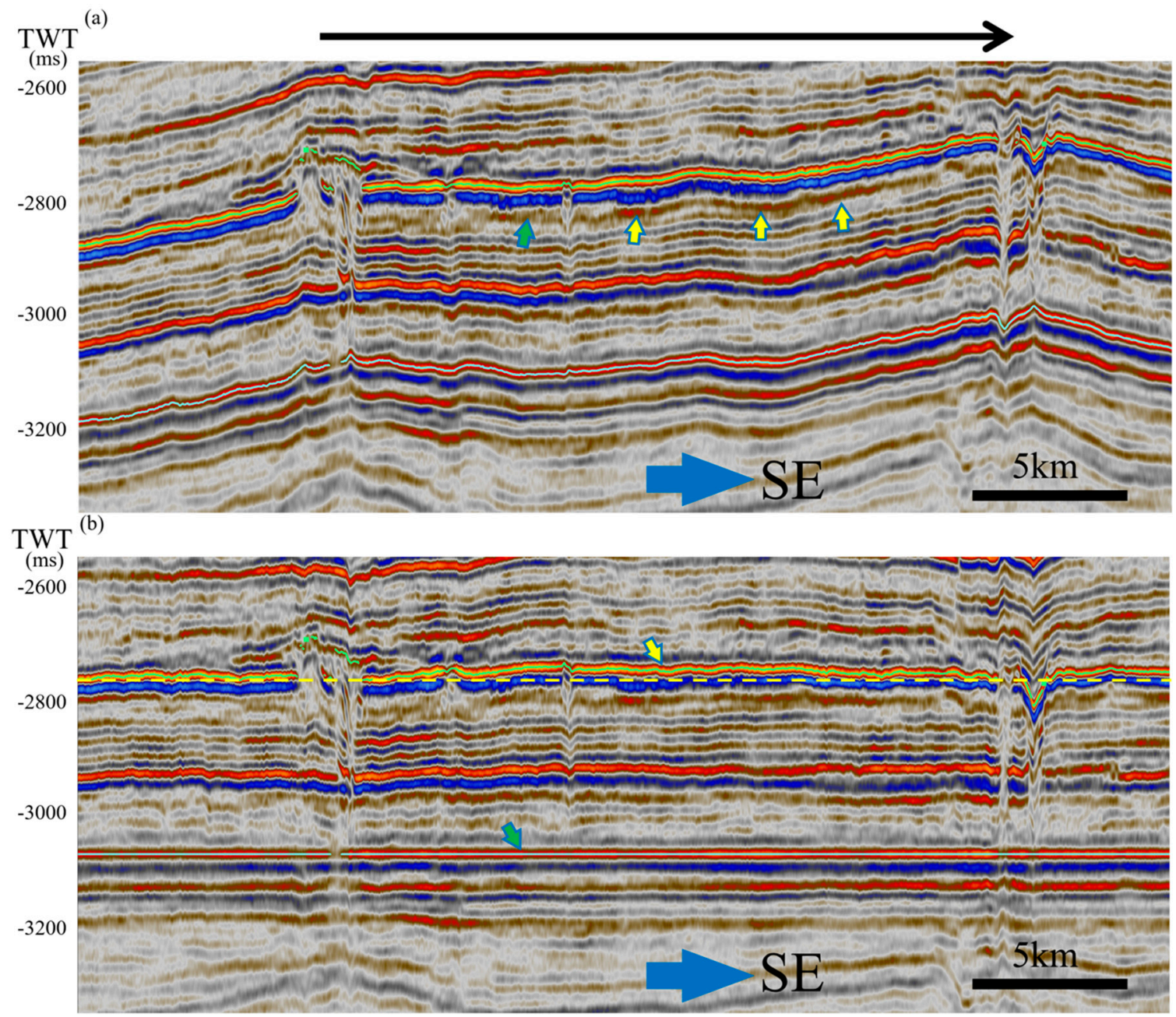

Figure A1. Seismic profile along the red arrow in Figure 4, showing the increasing tuning of basalt reflector. The bottom reflector (blue one) of the basalt layer from the center of the study area is not tuned; while that from the high-thickness area is tuned, which means the thickness of basalt here has reached the tuning limit. Wells T40 and T41, which have basalt thickness of $72 \mathrm{~m}$ and $76 \mathrm{~m}$, show tuning effect; while wells T39 and T35, which have basalt thickness of $52 \mathrm{~m}$ and $62 \mathrm{~m}$, show no tuning effect. This suggests that the tuning point should be slightly lower than $70 \mathrm{~m}$, which is concordant with a tuning point at $25 \mathrm{~Hz}$ main frequency and a velocity of basalt at $5800 \mathrm{~m} / \mathrm{s}$.

\section{References}

1. Alexander, R.C. On the emplacement of tabular granites. J. Geol. Soc. 1998, 155, 853-862. [CrossRef]

2. Hansen, D.M.; Cartwright, J. Saucer-shaped sill with lobate morphology revealed by 3D seismic data: Implications for resolving a shallow-level sill emplacement mechanism. J. Geol. Soc. 2006, 163, 509-523. [CrossRef]

3. Magee, C.; Hunt-Stewart, E.; Jackson, C.A.-L. Volcano growth mechanisms and the role of sub-volcanic intrusions: Insights from 2D seismic reflection data. Earth Planet. Sci. Lett. 2013, 373, 41-53. [CrossRef]

4. Magee, C.; Jackson, C.A.-L.; Hardman, J.P.; Reeve, M.T. Decoding sill emplacement and forced fold growth in the Exmouth Sub-basin, offshore northwest Australia: Implications for hydrocarbon exploration. Interpretation 2017, 5, SK11-SK22. [CrossRef]

5. Johnson, A.M.; Pollard, D.D. Mechanics of growth of some laccolithic intrusions in the Henry mountains, Utah, I. Tectonophysics 1973, 18, 261-309. [CrossRef]

6. Pollard, D.D.; Johnson, A.M. Mechanics of growth of some laccolithic intrusions in the Henry mountains, Utah, II. Tectonophysics 1973, 18, 311-354. [CrossRef]

7. Stearns, D.W.; Matthews, V., III. Faulting and Forced Folding in the Rocky Mountains Foreland. In Laramide Folding Associated with Basement Block Faulting in the Western United States; Geological Society of America: Boulder, CO, USA, 1978; Volume 151, pp. 1-37.

8. Sturkell, E.; Einarsson, P.; Sigmundsson, F.; Geirsson, H.; Ólafsson, H.; Pedersen, R.; Dalfsen, E.D.Z.-V.; Linde, A.T.; Sacks, S.I.; Stefánsson, R. Volcano geodesy and magma dynamics in Iceland. J. Volcanol. Geotherm. Res. 2006, 150, 14-34. [CrossRef] 
9. $\quad$ Sparks, R.S.J.; Biggs, J.; Neuberg, J.W. Monitoring Volcanoes. Science 2012, 335, 1310-1311. [CrossRef]

10. Ebmeier, S.K.; Andrews, B.J.; Araya, M.C.; Arnold, D.W.D.; Biggs, J.; Cooper, C.; Cottrell, E.; Furtney, M.; Hickey, J.; Jay, J.; et al. Synthesis of global satellite observations of magmatic and volcanic deformation: Implications for volcano monitoring \& the lateral extent of magmatic domains. J. Appl. Volcanol. 2018, 7, 2. [CrossRef]

11. Reeves, J.; Magee, C.; Jackson, C.A.-L. Unravelling intrusion-induced forced fold kinematics and ground deformation using 3D seismic reflection data. Volcanica 2018, 1, 1-17. [CrossRef]

12. Magee, C.; Hoggett, M.; Jackson, C.A.-L.; Jones, S.M. Burial-Related Compaction Modifies Intrusion-Induced Forced Folds: Implications for Reconciling Roof Uplift Mechanisms Using Seismic Reflection Data. Front. Earth Sci. 2019, 7, 37. [CrossRef]

13. Morgan, S.; Stanik, A.; Horsman, E.; Tikoff, B.; Blanquat, M.D.S.; Habert, G. Emplacement of multiple magma sheets and wall rock deformation: Trachyte Mesa intrusion, Henry Mountains, Utah. J. Struct. Geol. 2008, 30, 491-512. [CrossRef]

14. Schmiedel, T.; Kjoberg, S.; Planke, S.; Magee, C.; Galland, O.; Schofield, N.; Jackson, C.A.-L.; Jerram, D.A. Mechanisms of overburden deformation associated with the emplacement of the Tulipan sill, mid-Norwegian margin. Interpretation 2017, 5, SK23-SK38. [CrossRef]

15. Schmiedel, T.; Galland, O.; Haug, Ø.T.; Dumazer, G.; Breitkreuz, C. Coulomb failure of Earth's brittle crust controls growth, emplacement and shapes of igneous sills, saucer-shaped sills and laccoliths. Earth Planet. Sci. Lett. 2019, 510, 161-172. [CrossRef]

16. Schofield, N.J.; Brown, D.J.; Magee, C.; Stevenson, C.T. Sill morphology and comparison of brittle and non-brittle emplacement mechanisms. J. Geol. Soc. 2012, 169, 127-141. [CrossRef]

17. Galland, O.; Spacapan, J.B.; Rabbel, O.; Mair, K.; Soto, F.G.; Eiken, T.; Schiuma, M.; Leanza, H.A. Structure, emplacement mechanism and magma-flow significance of igneous fingers-Implications for sill emplacement in sedimentary basins. J. Struct. Geol. 2019, 124, 120-135. [CrossRef]

18. Spacapan, J.B.; Galland, O.; Leanza, H.A.; Planke, S. Igneous sill and finger emplacement mechanism in shale-dominated formations: A field study at Cuesta del Chihuido, Neuquén Basin, Argentina. J. Geol. Soc. 2016, 174, 422-433. [CrossRef]

19. Eide, C.H.; Schofield, N.; Jerram, D.A.; Howell, J.A. Basin-scale architecture of deeply emplaced sill complexes: Jameson Land, East Greenland. J. Geol. Soc. 2016, 174, 23-40. [CrossRef]

20. Mark, N.; Schofield, N.; Pugliese, S.; Watson, D.; Holford, S.; Muirhead, D.; Brown, R.; Healy, D. Igneous intrusions in the Faroe Shetland basin and their implications for hydrocarbon exploration; new insights from well and seismic data. Mar. Pet. Geol. 2018, 92, 733-753. [CrossRef]

21. Hansen, D.M.; Cartwright, J. The three-dimensional geometry and growth of forced folds above saucer-shaped igneous sills. J. Struct. Geol. 2006, 28, 1520-1535. [CrossRef]

22. Jackson, C.A.-L.; Schofield, N.; Golenkov, B. Geometry and controls on the development of igneous sill-related forced folds: A 2-D seismic reflection case study from offshore southern Australia. GSA Bull. 2013, 125, 1874-1890. [CrossRef]

23. Magee, C.; Bastow, I.D.; Vries, B.V.W.D.; Jackson, C.A.-L.; Hetherington, R.; Hagos, M.; Hoggett, M. Structure and dynamics of surface uplift induced by incremental sill emplacement. Geology 2017, 45, 431-434. [CrossRef]

24. Schofield, N.; Holford, S.P.; Millett, J.; Brown, D.J.; Jolley, D.W.; Passey, S.R.; Muirhead, D.; Grove, C.; Magee, C.; Murray, J.; et al. Regional magma plumbing and emplacement mechanisms of the Faroe-Shetland Sill Complex: Implications for magma transport and petroleum systems within sedimentary basins. Basin Res. 2017, 29, 41-63. [CrossRef]

25. Mark, N.; Schofield, N.; Gardiner, D.; Holt, L.; Grove, C.; Watson, D.; Alexander, A.; Poore, H. Overthickening of sedimentary sequences by igneous intrusions. J. Geol. Soc. 2019, 176, 46-60. [CrossRef]

26. Zhang, S.B.; Ni, Y.N.; Gong, F.H.; Lu, H.N.; Huang, Z.B.; Lin, H.L. A Guide to the Stratigraphic Investigation on the Periphery of the Tarim Basin; Petroleum Industry Press: Beijing, China, 2003; pp. 1-280.

27. Lu, S.; Li, H.; Zhang, C.; Niu, G. Geological and geochronological evidence for the Precambrian evolution of the Tarim Craton and surrounding continental fragments. Precambrian Res. 2008, 160, 94-107. [CrossRef]

28. Li, Z. Geochronology of Neoproterozoic syn-rift magmatism in the Yangtze Craton, South China and correlations with other continents: Evidence for a mantle superplume that broke up Rodinia. Precambrian Res. 2003, 122, 85-109. [CrossRef]

29. Yang, S.; Chen, H.; Li, Z.; Li, Y.; Yu, X.; Li, D.; Meng, L. Early Permian Tarim Large Igneous Province in northwest China. Sci. China Earth Sci. 2013, 56, 2015-2026. [CrossRef]

30. Tian, W.; Campbell, I.H.; Allen, C.M.; Guan, P.; Pan, W.; Chen, M.; Yu, H.; Zhu, W. The Tarim picrite-basalt-rhyolite suite, a Permian flood basalt from northwest China with contrasting rhyolites produced by fractional crystallization and anatexis. Contrib. Miner. Pet. 2010, 160, 407-425. [CrossRef]

31. Yang, J.; Zhu, W.; Guan, D.; Zhu, B.; Yuan, L.; Xiang, X.; Su, J.; He, J.; Wu, X. 3D seismic interpretation of subsurface eruptive centers in a Permian large igneous province, Tazhong Uplift, central Tarim Basin, NW China. Acta Diabetol. 2015, 105, 2311-2326. [CrossRef]

32. Xu, Y.-G.; Wei, X.; Luo, Z.-Y.; Liu, H.-Q.; Cao, J. The Early Permian Tarim Large Igneous Province: Main characteristics and a plume incubation model. Lithos 2014, 204, 20-35. [CrossRef]

33. Tian, W.; Wang, L.; Pan, L.; Gong, M.Y. A giant felsic pyroclastic flow eruption in the Tarim Flood Basalt Province. Acta Petrol. Sin. 2018, 34, 63-74.

34. Wang, L.; Tian, W.; Shi, Y.; Guan, P. Volcanic structure of the Tarim flood basalt revealed through 3-D seismological imaging. Sci. Bull. 2015, 60, 1448-1456. [CrossRef] 
35. Jackson, C.A.-L. Seismic reflection imaging and controls on the preservation of ancient sill-fed magmatic vents. J. Geol. Soc. 2012, 169, 503-506. [CrossRef]

36. Smallwood, J.R.; Maresh, J. The properties, morphology and distribution of igneous sills: Modelling, borehole data and 3D seismic from the Faroe-Shetland area. Geol. Soc. Lond. Spéc. Publ. 2002, 197, 271-306. [CrossRef]

37. Posamentier, H.W.; Doré, A.G.; Vining, B.A. Application of 3D seismic visualization techniques for seismic stratigraphy, seismic geomorphology and depositional systems analysis: Examples from fluvial to deep-marine depositional environments. Geol. Soc. Lond. Pet. Geol. Conf. Ser. 2005, 6, 1565-1576. [CrossRef]

38. Schofield, N.; Heaton, L.; Holford, S.P.; Archer, S.G.; Jackson, C.A.-L.; Jolley, D.W. Seismic imaging of 'broken bridges': Linking seismic to outcrop-scale investigations of intrusive magma lobes. J. Geol. Soc. 2012, 169, 421-426. [CrossRef]

39. Thomson, K.; Hutton, D. Geometry and growth of sill complexes: Insights using 3D seismic from the North Rockall trough. Bull. Volcanol. 2004, 66, 364-375. [CrossRef]

40. Wang, L.; Tian, W.; Shi, Y. Data Processing Methods for 3D Seismic Imaging of Subsurface Volcanoes: Applications to the Tarim Flood Basalt. J. Vis. Exp. 2017, 126, e55930. [CrossRef]

41. Widess, M.B. HOW thin is a thin bed? Geophysics 1973, 38, 1176-1180. [CrossRef]

42. Zeng, H.; John, A.; Katherine, G. How Thin Is a Thin Bed? An Alternative Perspective. In Proceedings of the 2008 SEG Annual Meeting, Las Vegas, NV, USA, 9-14 November 2008; pp. 834-838.

43. Rider, M.; Kennedy, M. The Geological Interpretation of Well Logs, 3rd ed.; Rider-French Consulting Ltd.: Glasgow, UK, 2011.

44. Li, D.; Yang, S.; Chen, H.; Cheng, X.; Li, K.; Jin, X.; Li, Z.; Li, Y.; Zou, S. Late Carboniferous crustal uplift of the Tarim plate and its constraints on the evolution of the Early Permian Tarim Large Igneous Province. Lithos 2014, 204, 36-46. [CrossRef]

45. Chevallier, L.; Woodford, A. Morpho-tectonics and mechanism of emplacement of the dolerite rings and sills of the western Karoo, South Africa. S. Afr. J. Geol. 1999, 102, 43-54.

46. Symonds, P.; Planke, S.; Frey, O.; Skogseid, J. Volcanic evolution of the Western Australian continental margin and its implications for basin development. Sediment. Basins West. Aust. 1998, 2, 33-54.

47. Wang, L.; Tian, W.; Wei, Z.H.; Gong, M.Y.; Li, X.M. Volcanic conduits of the Tarim Flood Basalt Province: 3D structure and thermogenic gas release. Acta Petrol. Sin. 2018, 34, 75-90.

48. Planke, S.; Rasmussen, T.; Rey, S.S.; Myklebust, R. Seismic Characteristics and Distribution of Volcanic Intrusions and Hydrothermal Vent Complexes in the Vøring and Møre Basins. In Geological Society, London, Petroleum Geology Conference Series; Geological Society of London: London, UK, 2005; Volume 6, pp. 833-844.

49. Polteau, S.; Ferre, E.C.; Planke, S.; Neumann, E.-R.; Chevallier, L. How are saucer-shaped sills emplaced? Constraints from the Golden Valley Sill, South Africa. J. Geophys. Res. Space Phys. 2008, 113, 104-117. [CrossRef]

50. Magee, C.; Jackson, C.A.-L.; Schofield, N. The influence of normal fault geometry on igneous sill emplacement and morphology. Geology 2013, 41, 407-410. [CrossRef]

51. Magee, C.L.; Jackson, C.A.L.; Schofield, N. Diachronous sub-volcanic intrusion along deep-water margins: Insights from the Irish Rockall Basin. Basin Res. 2014, 26, 85-105. [CrossRef]

52. Dragoni, M.; Bonafede, M.; Boschi, E. Downslope flow models of a Bingham liquid: Implications for lava flows. J. Volcanol. Geotherm. Res. 1986, 30, 305-325. [CrossRef]

53. Poppe, S.; Galland, O.; De Winter, N.; Goderis, S.; Claeys, P.; Debaille, V.; Boulvais, P.; Kervyn, M. Structural and Geochemical Interactions Between Magma and Sedimentary Host Rock: The Hovedøya Case, Oslo Rift, Norway. Geochem. Geophys. Geosyst. 2020, 21, 8685. [CrossRef]

54. Magee, C.; Maharaj, S.M.; Wrona, T.; Jackson, C.A.-L. Controls on the expression of igneous intrusions in seismic reflection data. Geosphere 2015, 11, 1024-1041. [CrossRef]

55. Yang, H.; Jing, B.; Chen, P.; Liu, X.; Li, T. Prediction of S-wave velocity in the wellblock ZG5-7, middle Tarim Basin. Nat. Gas Ind. 2012, 32, 25-27.

56. Friedman, G.M. Early Diagenesis and Lithification in Carbonate Sediments. J. Sediment. Res. 1964, 34, 777-813. [CrossRef] 